\title{
National Trends and Disparities in Hospitalization for Hypertensive Emergencies Among Medicare Beneficiaries, 1999-2019
}

\author{
Yuan Lu, ScD; $;{ }^{1,2}$ Yun Wang, PhD; ${ }^{1}$ Erica S. Spatz, MD, MHS; $;{ }^{1,2}$ Oyere Onuma MD, MSc; ${ }^{1,2}$ \\ Khurram Nasir, MD, MPH, MSc; ${ }^{3,4}$ Fatima Rodriguez, MD ${ }^{5}$; Karol E. Watson, MD, PhD ${ }^{6}$; \\ Harlan M. Krumholz, MD, SM ${ }^{1,2,7}$
}

${ }^{1}$ Center for Outcomes Research and Evaluation, Yale New Haven Hospital, New Haven, CT

${ }^{2}$ Section of Cardiovascular Medicine, Department of Medicine, Yale School of Medicine, New Haven, CT

${ }^{3}$ Division of Cardiovascular Prevention and Wellness, Houston Methodist DeBakey Heart and Vascular Center, Houston, TX

${ }^{4}$ Center for Outcomes Research, Houston Methodist Research Institute, Houston, TX

${ }^{5}$ Division of Cardiovascular Medicine, School of Medicine, Stanford University, Stanford, CA

${ }^{6}$ David Geffen School of Medicine, University of California, Los Angeles, Los Angeles, CA

${ }^{7}$ Department of Health Policy and Management, Yale School of Public Health, New Haven, CT

Corresponding author:

Harlan M. Krumholz, MD, SM

1 Church St, Suite 200, New Haven, CT, 06510

Phone: 203-764-5885

Email: harlan.krumholz@yale.edu

Word Count: 2967 (main text) 
medRxiv preprint doi: https://doi.org/10.1101/2021.06.16.21259053; this version posted June 20, 2021. The copyright holder for this preprint (which was not certified by peer review) is the author/funder, who has granted medRxiv a license to display the preprint in perpetuity.

It is made available under a CC-BY-NC-ND 4.0 International license.

\section{KEY POINTS}

Question: How have hospitalization rate for hypertensive emergencies among US adults aged 65 years and older changed between 1999 and 2019 and are there any differences across demographic and geographical subgroups?

Findings: In this serial cross-sectional study that included 397,238 individual Medicare fee-forservice beneficiaries, there was a marked increase in hospitalization rates for hypertensive emergencies from 1999 to 2019, and this increase was most pronounced among Black adults across age, sex, race, and dual-eligible strata. Significant national variation was observed, with the highest hospitalization rates generally in the South.

Meaning: Between 1999 and 2019, hospitalization rates for hypertensive emergencies increased substantially and differences across demographic and geographic subgroups persisted. 
medRxiv preprint doi: https://doi.org/10.1101/2021.06.16.21259053; this version posted June 20, 2021. The copyright holder for this preprint (which was not certified by peer review) is the author/funder, who has granted medRxiv a license to display the preprint in perpetuity.

It is made available under a CC-BY-NC-ND 4.0 International license .

\begin{abstract}
Importance: In the last two decades, hypertension control in the U.S. population has not improved, and there are widening disparities. Less is known, however, about progress in reducing hospitalizations related to hypertensive emergencies.
\end{abstract}

Objectives: To describe trends in national hospitalization rates for hypertensive emergencies, overall and by demographic and geographical subgroups.

Design, Setting and, Participants: Serial cross-sectional analysis of Medicare fee-for-service beneficiaries aged 65 years or older between 1999 and 2019 using Medicare denominator and inpatient files.

Main Outcome and Measures: Trends in hospitalization for hypertensive emergencies, overall and by specific subgroups.

Results: The sample consisted of 397,238 individual Medicare fee-for-service beneficiaries.

From 1999 through 2019, the annual hospitalization rates for hypertensive emergencies increased significantly from 51.5 to 125.9 per 100,000 beneficiary-years; this increase was most pronounced among the following subgroups: adults $\geq 85$ years (66.8 to 274.1 ), females (64.9 to 160.1), Blacks (144.4 to 369.5), and Medicare-Medicaid insured (dual eligible, 93.1 to 270.0). Across all subgroups, Black adults had the highest hospitalization rate in 2019, and there was a significant increase in the differences in hospitalizations between Blacks and Whites from 1999 to 2019. Marked geographic variation was also present, with the highest hospitalization rates in the South (so-called "Stroke Belt"). Among 3,143 counties and county-equivalents included in the study, less than $1 \%$ of counties either had no change $(n=7)$ or decreased $(n=20)$ hospitalization rates since 1999. Among patients hospitalized for a hypertensive emergency, the 
medRxiv preprint doi: https://doi.org/10.1101/2021.06.16.21259053; this version posted June 20, 2021. The copyright holder for this preprint (which was not certified by peer review) is the author/funder, who has granted medRxiv a license to display the preprint in perpetuity.

It is made available under a CC-BY-NC-ND 4.0 International license.

observed 30-day all-cause mortality rate decreased from $2.6 \%$ to $1.7 \%$ and 30 -day all-cause readmission rate decreased from $15.7 \%$ to $11.8 \%$.

Conclusions and Relevance: Among Medicare fee-for-service beneficiaries aged 65 years or older, hospitalization rates for hypertensive emergencies increased substantially and significantly from 1999 to 2019. Black adults had the largest increase in hospitalization rates across age, sex, race, and dual-eligible strata. There was significant national variation, with the highest rates generally in the South. 
medRxiv preprint doi: https://doi.org/10.1101/2021.06.16.21259053; this version posted June 20, 2021. The copyright holder for this preprint (which was not certified by peer review) is the author/funder, who has granted medRxiv a license to display the preprint in perpetuity.

It is made available under a CC-BY-NC-ND 4.0 International license .

\section{BACKGROUND}

In recent decades, the United States (US) has made little progress in hypertension control.

Despite the availability of effective treatment and increase in hypertension diagnosis and awareness, national hypertension control (defined as blood pressure <140/90mmHg) has dropped from $54 \%$ in $2013-2014$ to $44 \%$ in $2017-2018 .{ }^{1}$ Given the growing prevalence and devastating effects of uncontrolled hypertension, the Surgeon General recently issued a call to action to make hypertension control a national priority. ${ }^{2}$ A salient question is whether we have made any progress in preventing hospitalizations for hypertensive emergencies - acute severe blood pressure elevations that are associated with target organ damage and require urgent interventions. ${ }^{3}$ It is also unknown whether there are differences in hospitalization trends by age, sex, race and region over time.

Prior reports using data from the Nationwide Inpatient Sample indicate that hospitalization rates for hypertensive emergencies increased in the past decade; ${ }^{4-6}$ however, these studies focused on short time frames, were not able to capture the entire nation's experience, did not assess demographic or geographic differences, and were not well positioned to assess trends due to sampling issues. ${ }^{7}$ Thus, we lack a contemporary, comprehensive, national perspective on hospitalization trends for hypertensive emergencies and associated outcomes, including readmission and mortality, and how they vary by demographic subgroups and geography.

The Centers for Medicare \& Medicaid Services (CMS) is ideally positioned to provide information on trends in hospitalizations, mortality, and readmission outcomes nationally and by county. Accordingly, we studied all Medicare fee-for-service beneficiaries between 1999 and 2019 and evaluated hospitalization rates for hypertensive emergencies and longer-term outcomes, including 30-day readmission and 30-day mortality. Because substantial demographic and 
medRxiv preprint doi: https://doi.org/10.1101/2021.06.16.21259053; this version posted June 20, 2021. The copyright holder for this preprint (which was not certified by peer review) is the author/funder, who has granted medRxiv a license to display the preprint in perpetuity.

It is made available under a CC-BY-NC-ND 4.0 International license .

regional variation may exist in hypertension prevalence and outcomes, we evaluated rates of hospitalization and associated outcomes by demographic subgroups and county.

\section{METHODS}

\section{Study Population}

We identified all Medicare beneficiaries 65 years of age or older enrolled in the fee-forservice plan for at least 1 month from January 1999 to December 2019 using Medicare denominator files. For each year, we counted the total number of beneficiaries and calculated beneficiary-years to account for new enrollment, disenrollment, or death during the study period. We then linked beneficiary data with Medicare inpatient claims data to identify beneficiaries admitted with a primary discharge diagnosis of hypertensive emergency, hypertension urgency, or hypertension crisis (International Classification of Diseases, Ninth Revision, Clinical Modification codes [ICD-9 CM] of 401.0, 402.0x, 403.0x, 404.0x, and 405.0x from January 1, 1999, to September 31, 2015, ICD-10 CM code of I100, I119, I110, I120, I132, I150, and I158 from October 1, 2015, to September 31, 2016, ICD-10 CM code of I16.0, I16.1, I16.9 from October 1, 2016, to December 31, 2019, Supplemental eTable 1). No marked change in hospitalization was observed when switching codes from ICD-9 to ICD-10. Nevertheless, we reported the rates of hospitalization based on a 3-year interval to minimize the effect of changes in coding over time. We excluded hospitalizations with a secondary discharge diagnosis of hypertensive emergency since severe hypertension can occur in response to an acute illness and may not have been the primary driver of hospitalization. We obtained mortality data from the Medicare denominator files. 
medRxiv preprint doi: https://doi.org/10.1101/2021.06.16.21259053; this version posted June 20, 2021. The copyright holder for this preprint (which was not certified by peer review) is the author/funder, who has granted medRxiv a license to display the preprint in perpetuity.

It is made available under a CC-BY-NC-ND 4.0 International license .

\section{Patient Characteristics}

We determined the age, sex, and race (White, Black, Other) of beneficiaries and counted the number eligible for Medicaid for at least 1 month (dual eligible) for the Medicare fee-forservice beneficiaries who were hospitalized for hypertensive emergencies. The race variable was extracted from the Medicare enrollment database (EDB) and originates from Social Security Administration records. Before 1980, the Social Security Administration collected voluntary race data using the categories: White, Black, Other, and Unknown. The race of the beneficiary was assigned to the spouse. Given the EDB race variable is known to undercount Hispanics and other racial subgroups, analyses using race/ethnicity data from the EDB are generally restricted to the identification of differences between black and white patient populations. ${ }^{8,9} \mathrm{We}$ ascertained comorbidities from secondary diagnosis codes as well as from principal and secondary diagnosis codes from all hospitalizations for 12 months before the index hospitalization; data from 1998 were used for hospitalizations in 1999. These comorbidities were classified using the Hierarchical Condition Categories method. ${ }^{10,11}$

\section{Outcomes}

Our primary outcome was hospitalization for hypertensive emergencies. Secondary outcomes were 30-day all-cause mortality, 30-day all-cause readmission, and 30-day causespecific readmission rates. We calculated hypertension-specific hospitalization rates by dividing the total numbers of hypertensive emergency discharges in each year by the corresponding person years of fee-for-service beneficiaries for that year. ${ }^{12}$ To standardize the follow-up period, we used 30-day mortality rate, defined as the rate of deaths by all causes that occurred within 30 days from the date of admission of the index hospitalization for hypertensive emergency. We 
medRxiv preprint doi: https://doi.org/10.1101/2021.06.16.21259053; this version posted June 20, 2021. The copyright holder for this preprint (which was not certified by peer review) is the author/funder, who has granted medRxiv a license to display the preprint in perpetuity.

It is made available under a CC-BY-NC-ND 4.0 International license .

defined 30-day readmission as hospitalizations for all causes occurring within 30 days from the date of discharge from the index hospitalization, using November 30, 2019, as the final date of discharge for complete follow up. ${ }^{10-12}$ We further defined the condition-specific readmission rates for the principal discharge diagnoses of congestive heart failure $(\mathrm{CHF})$, acute myocardial infarction (AMI), and stroke (see Supplemental eTable 1 for a list of ICD-9 and ICD-10 codes). If a patient had more than one hospitalization for hypertensive emergencies during the study period, we counted them all for the hospitalization analysis but randomly selected one for the mortality and readmission analysis.

\section{Statistical Analysis}

We expressed the rates of hypertensive emergency hospitalizations as per 100,000 beneficiary-years, the rates of 30-day all-cause mortality and readmission as percentages. To assess trends in rates of hospitalization for hypertensive emergencies, we fit a mixed effects model with a Poisson link function and state-specific random intercepts, adjusting for age, sex, dual-eligible status, and race. To assess trends in the rates of 30-day mortality, we constructed a Cox proportional hazards regression to model the mortality as a function of patient age, sex, dual-eligible status, race, and comorbidity. We repeated this model for the 30 -day readmission. Patients who switched to the Medicare Advantage plan after the initial hospitalization for hypertensive emergencies were treated as lost to follow-up, and deaths prior to a readmission were accounted using the Fine and Gray method ${ }^{13}$ for competing risks. We checked the adequacy of the Cox regression model and found that the proportional hazards assumption was satisfied. ${ }^{14}$ For all models, time was modeled as an ordinal variable, corresponding to the years 1999 
medRxiv preprint doi: https://doi.org/10.1101/2021.06.16.21259053; this version posted June 20, 2021. The copyright holder for this preprint (which was not certified by peer review) is the author/funder, who has granted medRxiv a license to display the preprint in perpetuity.

It is made available under a CC-BY-NC-ND 4.0 International license .

(time=0) to 2019 (time=20), to represent the adjusted annual percent change in each outcome.

We repeated models for age, sex, race, and dual status subgroups.

To assess geographic trends and variation in hospitalizations, we extended the CMS model used for profiling hospital performance on outcomes ${ }^{13}$ with a Poisson link function to model the number of hospitalizations for hypertensive emergencies as a function of patients' age, sex, dual-eligible status, and race. We then calculated a risk-standardized number of hospitalizations per 100,000 beneficiary-years for each county and the beginning of (1999-2001) and ending (2017-2019) study periods. We mapped counties using a gradient from red, yellow, and green (increase in red, on average in yellow, and decrease in green). ${ }^{15,16} \mathrm{We}$ also calculated a Pearson correlation coefficient between the 1999-2001 and 2017-2019 periods to evaluate the change in hospitalizations geographically.

All analyses were conducted using SAS version 9.4 (SAS Institute Inc.). All statistical testing was 2-sided at a significance level of 0.05 . Institutional review board approval for this study was obtained through the Yale University Human Investigation Committee. The study followed the guidelines for cohort studies, described in the Strengthening the Reporting of Observational Studies in Epidemiology (STROBE) Statement: guidelines for reporting observational studies. ${ }^{17}$

\section{RESULTS}

\section{Patient Characteristics and Comorbidities}

The study sample consisted of 449,865 hypertension emergency-specific discharges (i.e., malignant hypertension, hypertensive heart disease, hypertensive renal disease, hypertensive emergency, hypertensive urgency, hypertensive crisis), represented 397,238 unique beneficiaries 
medRxiv preprint doi: https://doi.org/10.1101/2021.06.16.21259053; this version posted June 20, 2021. The copyright holder for this preprint (which was not certified by peer review) is the author/funder, who has granted medRxiv a license to display the preprint in perpetuity.

It is made available under a CC-BY-NC-ND 4.0 International license .

65 years of age or older with $\geq 1$ month of enrollment in the Medicare fee-for-service plan during the 21-year study period. Between 1999-2001 and 2017-2019, the average age of patients increased slightly (76.7 years [SD: 7.4] vs 77.9 years [SD: 8.7]), the proportion of female patients declined from $74.9 \%$ to $68.7 \%$, White patients decreased from $74.9 \%$ to $70.7 \%$, and Black patients increased from $20.3 \%$ to $21.3 \%$. Several comorbidities were more commonly coded in 2017-2019 (Table 1), including renal failure (10.7\% in 1999-2001 vs. 38.6\% in 20172019), respiratory failure (2.5\% in $1999-2001$ vs. $7.5 \%$ in $2017-2019)$, and diabetes mellitus (29.6\% in 1999-2001 vs. $39.2 \%$ in 2017-2019). All p values were <0.001 for trend.

Trends in Hospitalization for Hypertensive Emergencies Overall and by Demographic

\section{Subgroups}

Between 1999-2019, the observed rate of hospitalization for hypertension emergencies among Medicare fee-for-service beneficiaries increased significantly from 51.5 to 125.9 per 100,000 beneficiary-years (Figure 1). Among Medicare beneficiaries, the increase in hospitalization for hypertensive emergencies was most pronounced among those who were $\geq 85$ years of age (66.8 to 274.1), females (64.9 to 160.1), Black people (144.4 to 369.5), and dualeligible (93.1 to 270.0; Figure 2). Across all age, sex, race, and dual-eligible strata, differences by race in hospitalizations for hypertensive emergencies increased substantially, with a rate of 369.5 per 100,000 beneficiary-years among Black beneficiaries compared with 104.8 per 100,000 beneficiary-years among White beneficiaries in 2019. These findings did not change substantially after adjusting for beneficiaries' demographic characteristics. After adjusting for age, sex, race and dual-eligible status, the overall annual hypertensive emergency-hospitalization rate increased by 5.6\% (95\% CI 5.51-5.61); among Black beneficiaries the annual increase of 
medRxiv preprint doi: https://doi.org/10.1101/2021.06.16.21259053; this version posted June 20, 2021. The copyright holder for this preprint (which was not certified by peer review) is the author/funder, who has granted medRxiv a license to display the preprint in perpetuity.

It is made available under a CC-BY-NC-ND 4.0 International license .

$6.0 \%$ (95\% CI 4.89-6.11) was more pronounced than in White beneficiaries (5.4\%, CI 5.35-5.48)

\section{(Supplemental eFigure 1).}

\section{Geographical Variation in Hospitalization for Hypertensive Emergencies}

We observed marked geographic variation in hospitalization rates for hypertensive emergencies at the county level, with higher rates in the South, Mid-Atlantic, and Northwest in 1999-2001 (Figure 3, panel A); this was persistent in 2017-2019 (Figure 3, panel B). The Pearson correlation coefficient of county-specific hospitalization rates between 1999-2001 and 2017-2019 was 0.34 (95\% CI: 0.30-0.37), indicating that the geographic pattern of hospitalization rates persisted moderately. The increase in hospitalization rates over the study period was observed geographically. Among 3,143 counties and county-equivalents included in the study, less than $1 \%$ counties either had no change $(n=7)$ or decreased $(n=20)$ hospitalization rates and the majority of counties $(n=3,116)$ had increased hospitalization rates (Figure $\mathbf{3}$, panel C).

\section{Trends in Mortality and Readmission Rates Among Hospitalized Patients}

Among beneficiaries hospitalized for hypertensive emergencies, the observed 30-day allcause mortality decreased from 2.6\% (95\% CI, 2.27-2.83) in 1999 to $1.7 \%$ in 2019 (95\% CI, 1.53-1.80), and the observed 30-day all-cause readmission decreased from $15.7 \%$ (95\% CI, 15.116.4) to $11.8 \%$ (95\% CI, 11.5-12.1, Supplemental eFigure 2). No significant change was found in the rates of 30-day readmission for AMI (0.4\% [95\% CI $0.31-0.54]$ in 1999 and $0.4 \%$ [95\% CI 0.30-.43] in 2019), but a marked decrease was observed in the rates of CHF from $2.5 \%$ (95\% CI, $2.25-2.82)$ to $1.5 \%(95 \% \mathrm{CI}, 1.42-1.68)$, in the rates of stroke from $0.8 \%$ (95\% CI, $0.62-0.93)$ to 
medRxiv preprint doi: https://doi.org/10.1101/2021.06.16.21259053; this version posted June 20, 2021. The copyright holder for this preprint (which was not certified by peer review) is the author/funder, who has granted medRxiv a license to display the preprint in perpetuity.

It is made available under a CC-BY-NC-ND 4.0 International license .

$0.5 \%$ (95\% CI, 0.46-0.61), and in the rates of $\mathrm{AMI} / \mathrm{CHF} /$ stroke combined from $5.2 \%$ (95\% CI, $4.78-5.58)$ to $3.8 \%(95 \% \mathrm{CI}, 3.57-3.97)$.

These trends were similar among all age, sex, race, and dual status strata (Figure 4). After accounting for patient characteristics, the adjusted annual decrease rates were $2.3 \%$ (95\% CI $2.20-2.45), 2.6 \%$ (95\% ci $2.45-2.72), 2.5 \%$ (95\% CI 2.35-2.61), 2.4\% (95\% CI 2.25-2.51), $2.4 \%(2.26-2.52)$, and $2.5 \%(2.37-2.64)$, for 30-day all-cause mortality, all-cause readmissions, CHF-specific, AMI-specific, stroke-specific, and AMI/CHF/stroke readmissions, respectively.

\section{DISCUSSION}

In this comprehensive analysis of the hospital trends in the Medicare fee-for-service population aged 65 years or older, we found a marked increase in hospitalization for hypertensive emergencies between 1999 and 2019. The increase was most pronounced among Black Medicare beneficiaries, the age group $>85$ years, women, and dual-eligible, with Black individuals having the largest 20-year increase across all age, sex, race, and dual-eligible strata. This overall trend was consistent nationwide, although geographic variation was present. Counties in the South (so-called "Stroke Belt") had the highest rates of hospitalization.

This study adds to the literature in several ways. This study is the most contemporary study of the Medicare Fee-For-Service population and provides direct evidence of the failure of the clinical and public health interventions in reducing the risk of hospitalizations for hypertensive emergencies. The findings are concordant with evidence that age-adjusted mortality from hypertension is rising, stroke rates are rising, and hypertension control is declining. Moreover, Black adults have the highest rates of hospitalization for hypertensive emergency with the steepest increase in rates. Previous studies ${ }^{4-6}$ with different analyses that used National 
medRxiv preprint doi: https://doi.org/10.1101/2021.06.16.21259053; this version posted June 20, 2021. The copyright holder for this preprint (which was not certified by peer review) is the author/funder, who has granted medRxiv a license to display the preprint in perpetuity.

It is made available under a CC-BY-NC-ND 4.0 International license .

Inpatient Sample data from 2000 to 2012, have showed results that were broadly consistent even as they focused on shorter time frames and did not examine variations by population subgroups.

Since the study uses administrative codes, it is important to examine if this may be artifactual. Polgreen and colleagues ${ }^{6}$ hypothesized that a shift towards assigning more severe diagnoses in administrative billing codes might have accounted for the increased hospitalization for hypertensive emergencies. However, the Polgreen's study used data before 2011 and we also observed a marked increase in hospitalization for hypertensive emergencies rate after 2011. It seems implausible that coding shifts could have accounted for the marked changes over the whole 20-year period we observed. The increase in hospitalization was also unlikely associated with the change in ICD-9 to ICD-10 diagnosis coding in 2015 since the observed increase in hospitalization started in 2007. Moreover, the strongest case for the finding reflecting the true experience of patients is that we find consistency with the studies of hypertensive heart disease mortality, stroke mortality, and hypertension control. During the study period, hypertensive disease mortality rate among US adults aged 65 years and older increased from 98.4 in 1999 to 140.0 per 100,000 population in $2018 .^{18,19}$ Stroke-related mortality rates declined from 1999 to 2011, and then markedly increased from 2012 to 2018 such that the stroke related mortality rate in 2018 was equal to the rate observed in 2000. Hypertension control rate among US adults aged 65 years and older decreased from $54.1 \%$ in 2013 to $44.5 \%$ in $2018 .{ }^{1}$ This consistent evidence suggests that the marked increase in hospitalization for hypertensive emergency, especially while health care costs are rising, are of great concern.

A striking finding of this study was highlighted by the rapid increase in racial disparities of hospitalization for hypertensive emergencies between Black and White beneficiaries, with Black individuals consistently having the higher rates during the last 20 years. Moreover, 
medRxiv preprint doi: https://doi.org/10.1101/2021.06.16.21259053; this version posted June 20, 2021. The copyright holder for this preprint (which was not certified by peer review) is the author/funder, who has granted medRxiv a license to display the preprint in perpetuity.

It is made available under a CC-BY-NC-ND 4.0 International license .

stratification by age, sex, and dual-eligible status showed persistent racial differences across strata. Such findings are especially important given hypertension disproportionally affects Black people. Compared with White people, hypertension in Black people occurs at an earlier age, is more severe, and is more likely to be associated with end-organ damage such as stroke, myocardial infarction, renal failure and death. ${ }^{20,21}$ Although there have been national attention and a wide variety of public health programs to address racial differences in health, ${ }^{22-24}$ this study demonstrated worsening health inequities with respect to acute hospitalization for hypertensive emergencies, highlighting the need for new approaches to address both medical and nonmedical factors that contribute to such inequities, including systemic racism, ${ }^{25-29}$ poor hypertension control, $^{30-32}$ and high prevalence of renal diseases ${ }^{33,34}$ among Black individuals.

Furthermore, our study evaluates several longer-term outcomes after hospitalization for hypertensive emergencies that have not been studied in a national cohort. We showed improved mortality and readmission rates among those hospitalized and these improvements were consistent across age, sex, race, and dual-eligible subgroups. These improvements may, in part, be associated with national efforts to improve the care of all patients across the study period. ${ }^{35-40}$ Studies have showed improvements in process measures and outcomes for many conditions in Medicare beneficiaries. ${ }^{15,16,41}$ Additionally, improvements in outcomes observed may have been related to advance in treatments and health technologies. For example, the use of statins for prevention, the expansion of coronary revascularization, and the improvement in use of evidence-based medications are likely contributing to a lower risk of repeat hospitalization and improved survival associated with cardiovascular diseases. ${ }^{42-44}$ These results suggest that we have made progress in improving outcomes once patients are hospitalized for an acute illness; the issue is more about preventing hospitalizations for hypertensive emergencies. 
medRxiv preprint doi: https://doi.org/10.1101/2021.06.16.21259053; this version posted June 20, 2021. The copyright holder for this preprint (which was not certified by peer review) is the author/funder, who has granted medRxiv a license to display the preprint in perpetuity.

It is made available under a CC-BY-NC-ND 4.0 International license .

\section{Limitations}

This study has several limitations. First, we studied only Medicare fee-for-service beneficiaries and the results in this elderly population may not be fully generalizable to the broader US national population. However, this database represents the most complete national data for assessing rates of hospitalization and long-term outcomes. Second, we used administrative claims alone for the identification of hypertensive emergencies and could not confirm the diagnosis with blood pressure measurements and other clinically relevant prognostic factors. It is possible that changes in ICD coding practices could have affected our results. Nevertheless, previous studies by our group have shown that the performance of administrative data-based models for heart failure and myocardial infarction is comparable to that of the medical chart abstract-based models. ${ }^{10,11}$ Third, we defined hospitalization for hypertension emergencies based on primary discharge diagnosis and this will likely lead to underestimation of the number of hospitalization because some patients may have secondary diagnosis for hypertension emergency. Fourth, this study only examined hospitalizations and did not include Emergencies Department visits and outpatient visits. As a substantial proportion of the patients with hypertensive emergencies were managed in the Emergencies Department visits, ${ }^{4-6}$ our study is likely to underestimate the total medical needs of hypertensive emergencies. Fifth, we could not show what accounted for the changes in 30-day outcomes after hospitalization for hypertensive emergencies due to limited data available in the administrative claim database. Finally, we did not examine trends in Hispanic and other racial/ethnic subgroups due to misclassification of race in the Medicare data. ${ }^{8,9}$ 
medRxiv preprint doi: https://doi.org/10.1101/2021.06.16.21259053; this version posted June 20, 2021. The copyright holder for this preprint (which was not certified by peer review) is the author/funder, who has granted medRxiv a license to display the preprint in perpetuity.

It is made available under a CC-BY-NC-ND 4.0 International license.

\section{Conclusion}

Among Medicare fee-for-service beneficiaries aged 65 years or older, hospitalization rates for hypertensive emergencies increased significantly from 1999 to 2019. Black beneficiaries had the largest increase in hospitalization rates for hypertensive emergencies across all age, sex, race, and dual-eligible strata. There was significant national variation, with the highest hospitalization rates generally in the South. 
medRxiv preprint doi: https://doi.org/10.1101/2021.06.16.21259053; this version posted June 20, 2021. The copyright holder for this preprint (which was not certified by peer review) is the author/funder, who has granted medRxiv a license to display the preprint in perpetuity.

It is made available under a CC-BY-NC-ND 4.0 International license .

\section{ACKNOWLEDGEMENTS}

\section{Funding: None.}

Disclosures: In the past three years, Dr. Krumholz received expenses and/or personal fees from UnitedHealth, IBM Watson Health, Element Science, Aetna, Facebook, the Siegfried and Jensen Law Firm, Arnold and Porter Law Firm, Martin/Baughman Law Firm, F-Prime, and the National Center for Cardiovascular Diseases in Beijing. He is a co-founder of Refactor Health and HugoHealth and had grants and/or contracts from the Centers for Medicare \& Medicaid Services, Medtronic, the U.S. Food and Drug Administration, Johnson \& Johnson, and the Shenzhen Center for Health Information. Dr. Lu is supported by the National Heart, Lung, and Blood Institute (K12HL138037) and the Yale Center for Implementation Science. She was a recipient of a research agreement, through Yale University, from the Shenzhen Center for Health Information for work to advance intelligent disease prevention and health promotion. The other co-authors report no potential competing interests.

Access to Data Statement: Dr. Lu and Mr. Liu had full access to all the data in the study and take responsibility for the integrity of the data and the accuracy of the data analysis. 
medRxiv preprint doi: https://doi.org/10.1101/2021.06.16.21259053; this version posted June 20, 2021. The copyright holder for this preprint (which was not certified by peer review) is the author/funder, who has granted medRxiv a license to display the preprint in perpetuity.

It is made available under a CC-BY-NC-ND 4.0 International license .

\section{References:}

1. Muntner P, Hardy ST, Fine LJ, et al. Trends in Blood Pressure Control Among US Adults With Hypertension, 1999-2000 to 2017-2018. Jama. 2020.

2. Adams JM, Wright JS. A National Commitment to Improve the Care of Patients With Hypertension in the US. Jama. 2020.

3. Papadopoulos DP, Mourouzis I, Thomopoulos C, Makris T, Papademetriou V. Hypertension crisis. Blood Press. 2010;19(6):328-336.

4. Shah M, Patil S, Patel B, et al. Trends in Hospitalization for Hypertensive Emergency, and Relationship of End-Organ Damage With In-Hospital Mortality. Am J Hypertens. 2017;30(7):700-706.

5. Janke AT, McNaughton CD, Brody AM, Welch RD, Levy PD. Trends in the Incidence of Hypertensive Emergencies in US Emergency Departments From 2006 to 2013. J Am Heart Assoc. 2016;5(12).

6. Polgreen LA, Suneja M, Tang F, Carter BL, Polgreen PM. Increasing trend in admissions for malignant hypertension and hypertensive encephalopathy in the United States. Hypertension. 2015;65(5):1002-1007.

7. Khera R, Angraal S, Couch T, et al. Adherence to Methodological Standards in Research Using the National Inpatient Sample. Jama. 2017;318(20):2011-2018.

8. Filice CE, Joynt KE. Examining Race and Ethnicity Information in Medicare Administrative Data. Medical care. 2017;55(12):e170-e176.

9. Jarrin OF, Nyandege AN, Grafova IB, Dong X, Lin H. Validity of Race and Ethnicity Codes in Medicare Administrative Data Compared With Gold-standard Self-reported 
medRxiv preprint doi: https://doi.org/10.1101/2021.06.16.21259053; this version posted June 20, 2021. The copyright holder for this preprint (which was not certified by peer review) is the author/funder, who has granted medRxiv a license to display the preprint in perpetuity.

It is made available under a CC-BY-NC-ND 4.0 International license .

Race Collected During Routine Home Health Care Visits. Medical care. 2020;58(1):e1e8.

10. Krumholz HM, Wang Y, Mattera JA, et al. An administrative claims model suitable for profiling hospital performance based on 30-day mortality rates among patients with heart failure. Circulation. 2006;113(13):1693-1701.

11. Krumholz HM, Wang Y, Mattera JA, et al. An administrative claims model suitable for profiling hospital performance based on 30-day mortality rates among patients with an acute myocardial infarction. Circulation. 2006;113(13):1683-1692.

12. Chen J, Normand SL, Wang Y, Krumholz HM. National and regional trends in heart failure hospitalization and mortality rates for Medicare beneficiaries, 1998-2008. Jama. 2011;306(15):1669-1678.

13. Fine JP, Gray RJ. A proportional hazards model for the subdistribution of a competing risk. Journal of the American statistical association. 1999;94(446):496-509.

14. Lin DY, Wei L-J, Ying Z. Checking the Cox model with cumulative sums of martingalebased residuals. Biometrika. 1993;80(3):557-572.

15. Krumholz HM, Normand S-LT, Wang Y. Trends in hospitalizations and outcomes for acute cardiovascular disease and stroke, 1999-2011. Circulation. 2014;130(12):966-975.

16. Krumholz HM, Nuti SV, Downing NS, Normand SL, Wang Y. Mortality, Hospitalizations, and Expenditures for the Medicare Population Aged 65 Years or Older, 1999-2013. Jama. 2015;314(4):355-365.

17. Von Elm E, Altman DG, Egger M, et al. The Strengthening the Reporting of Observational Studies in Epidemiology (STROBE) Statement: guidelines for reporting observational studies. International journal of surgery. 2014;12(12):1495-1499. 
medRxiv preprint doi: https://doi.org/10.1101/2021.06.16.21259053; this version posted June 20, 2021. The copyright holder for this preprint (which was not certified by peer review) is the author/funder, who has granted medRxiv a license to display the preprint in perpetuity.

It is made available under a CC-BY-NC-ND 4.0 International license .

18. Centers for Disease Control and Prevenetion. Wide-ranging Online Data for Epidemiologic Research database.https://wonder.cdc.gov/. Accessed on April 17, 2021.

19. Shah NS, Lloyd-Jones DM, O'Flaherty M, et al. Trends in cardiometabolic mortality in the United States, 1999-2017. Jama. 2019;322(8):780-782.

20. Lackland DT. Racial differences in hypertension: implications for high blood pressure management. Am J Med Sci. 2014;348(2):135-138.

21. Rodriguez F, Ferdinand KC. Hypertension in minority populations: new guidelines and emerging concepts. Adv Chronic Kidney Dis. 2015;22(2):145-153.

22. U.S. Department of Health and Human Services. About the Office of Minority Health. https://www.minorityhealth.hhs.gov/omh/browse.aspx?lvl=1\&lvlid=1. Accessed March $16,2021$.

23. Koh HK, Graham G, Glied SA. Reducing racial and ethnic disparities: the action plan from the Department of Health and Human Services. Health Aff (Millwood). 2011;30(10):1822-1829.

24. U.S. Department of Health and Human Services. Health People. Foundation health measures archive: disparities. https://www.healthypeople.gov/2020/about/foundationhealth-measures/Disparities. Accessed March 16, 2021.

25. Cogburn CD. Culture, race, and health: implications for racial inequities and population health. The Milbank Quarterly. 2019;97(3):736-761.

26. Macintosh T, Desai MM, Lewis TT, Jones BA, Nunez-Smith M. Socially-assigned race, healthcare discrimination and preventive healthcare services. PLoS One. 2013;8(5):e64522. 
medRxiv preprint doi: https://doi.org/10.1101/2021.06.16.21259053; this version posted June 20, 2021. The copyright holder for this preprint (which was not certified by peer review) is the author/funder, who has granted medRxiv a license to display the preprint in perpetuity. It is made available under a CC-BY-NC-ND 4.0 International license .

27. Phelan JC, Link BG. Is racism a fundamental cause of inequalities in health? Annu Rev Sociol. 2015;41(1):311-330.

28. Alcalá HE, Chen J, Langellier BA, Roby DH, Ortega AN. Impact of the Affordable Care Act on health care access and utilization among Latinos. J Am Board Fam Med. 2017;30(1):52-62.

29. Churchwell K, Elkind MSV, Benjamin RM, et al. Call to Action: Structural Racism as a Fundamental Driver of Health Disparities: A Presidential Advisory From the American Heart Association. Circulation. 2020;142(24):e454-e468.

30. Muntner P, Carey RM, Gidding S, et al. Potential US Population Impact of the 2017 ACC/AHA High Blood Pressure Guideline. Circulation. 2018;137(2):109-118.

31. Gu A, Yue Y, Desai RP, Argulian E. Racial and Ethnic Differences in Antihypertensive Medication Use and Blood Pressure Control Among US Adults With Hypertension: The National Health and Nutrition Examination Survey, 2003 to 2012. Circ Cardiovasc Qual Outcomes. 2017;10(1).

32. Muntner P, Hardy ST, Fine LJ, et al. Trends in Blood Pressure Control Among US Adults With Hypertension, 1999-2000 to 2017-2018. JAMA. 2020;324(12):1190-1200.

33. Nicholas SB, Kalantar-Zadeh K, Norris KC. Racial disparities in kidney disease outcomes. Paper presented at: Seminars in nephrology2013.

34. Norris KC, Agodoa LY. Unraveling the racial disparities associated with kidney disease1. Kidney international. 2005;68(3):914-924.

35. Costante PA. AMAP: toward standardized physician quality data. American Medical Accreditation Program. N J Med. 1999;96(10):47-48. 
medRxiv preprint doi: https://doi.org/10.1101/2021.06.16.21259053; this version posted June 20, 2021. The copyright holder for this preprint (which was not certified by peer review) is the author/funder, who has granted medRxiv a license to display the preprint in perpetuity.

It is made available under a CC-BY-NC-ND 4.0 International license .

36. Ellerbeck EF, Jencks SF, Radford MJ, et al. Quality of care for Medicare patients with acute myocardial infarction. A four-state pilot study from the Cooperative Cardiovascular Project. Jama. 1995;273(19):1509-1514.

37. Marciniak TA, Ellerbeck EF, Radford MJ, et al. Improving the quality of care for Medicare patients with acute myocardial infarction: results from the Cooperative Cardiovascular Project. Jama. 1998;279(17):1351-1357.

38. Larson JS, Muller A. Managing the quality of health care. J Health Hum Serv Adm. $2002 ; 25(3): 261-280$.

39. Sawin CT, Walder DJ, Bross DS, Pogach LM. Diabetes process and outcome measures in the Department of Veterans Affairs. Diabetes care. 2004;27 Suppl 2:B90-94.

40. Jencks SF, Wilensky GR. The health care quality improvement initiative. A new approach to quality assurance in Medicare. Jama. 1992;268(7):900-903.

41. Freeman JV, Wang Y, Akar J, Desai N, Krumholz H. National Trends in Atrial Fibrillation Hospitalization, Readmission, and Mortality for Medicare Beneficiaries, 1999-2013. Circulation. 2017;135(13):1227-1239.

42. Kesselheim AS, Avorn J. The most transformative drugs of the past 25 years: a survey of physicians. Nat Rev Drug Discov. 2013;12(6):425-431.

43. Mann D, Reynolds K, Smith D, Muntner P. Trends in statin use and low-density lipoprotein cholesterol levels among US adults: impact of the 2001 National Cholesterol Education Program guidelines. Ann Pharmacother. 2008;42(9):1208-1215.

44. Roe MT, Messenger JC, Weintraub WS, et al. Treatments, trends, and outcomes of acute myocardial infarction and percutaneous coronary intervention. Journal of the American College of Cardiology. 2010;56(4):254-263. 
medRxiv preprint doi: https://doi.org/10.1101/2021.06.16.21259053; this version posted June 20, 2021. The copyright holder for this preprint (which was not certified by peer review) is the author/funder, who has granted medRxiv a license to display the preprint in perpetuity.

It is made available under a CC-BY-NC-ND 4.0 International license.

\section{FIGURE LEGENDS}

Figure 1. Observed Trends in Hospitalization Rate for Hypertensive Emergencies in the Medicare Fee-for-service Population, 1999-2019.

Figure 2. Trends in Observed Hospitalization Rate for Hypertensive Emergencies in the Medicare Fee-for-service Population by Age, Sex, Race, Dual Status, 1999-2019.

Figure 3. Maps Showing Trends in Risk-Standardized Hospitalization Rate for Hypertensive Emergencies in the Medicare Fee-for-service Population for Individual US Counties, 1999-2019.

Panel A: Risk-Standardized Hospitalization Rate for Hypertensive Emergencies for Individual US Counties, 1999-2001.

Panel B: Risk-Standardized Hospitalization Rate for Hypertensive Emergencies for Individual US Counties, 2017-2019.

Panel C: Correlation Between Risk-Standardized Hospitalization Rate for Hypertensive Emergencies for Individual US Counties in 1999-2001 and 2017-2019.

Figure 4. Average Annual Change in Hypertension Outcomes, Overall and by Subgroups.

Panel A: Overall Average Annual Change in Hypertension Outcomes.

Panel B: Overall Average Annual Change in Hypertension Outcomes by Subgroups. 
Table 1. Characteristics of Patients Hospitalized for Hypertensive emergencies, 1999 to 2019.

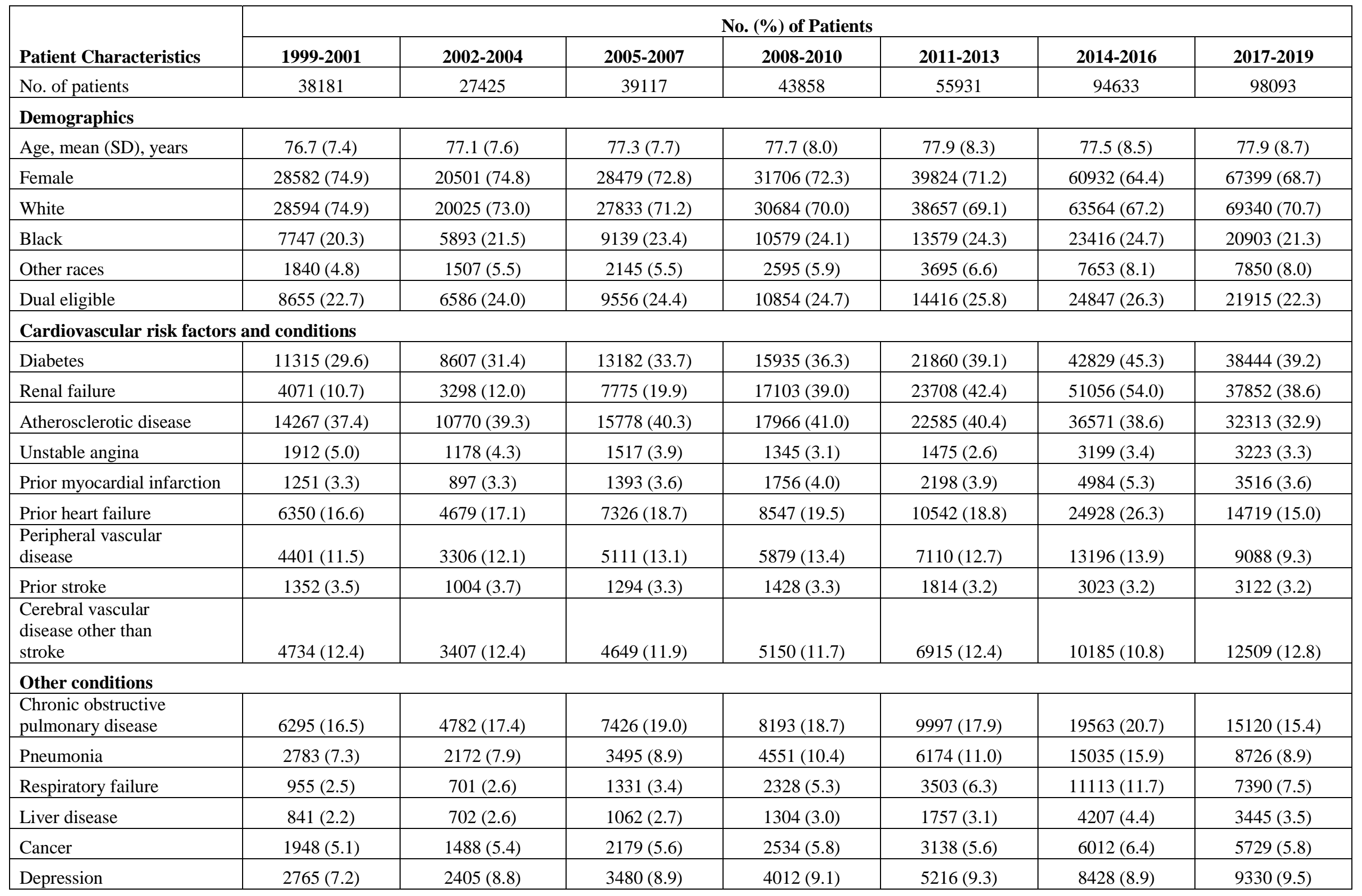


Other major psychiatric

disorders

Trauma in past year
$1116(2.9)$

$2049(5.4)$
$854(3.1)$ $1613(5.9)$
1246 (3.2)

2595 (6.6)
$1474(3.4)$

2933 (6.7)
2167 (3.9)

3663 (6.5)
3414 (3.6) 6227 (6.6)
$3346(3.4)$

$5878(6.0)$ 


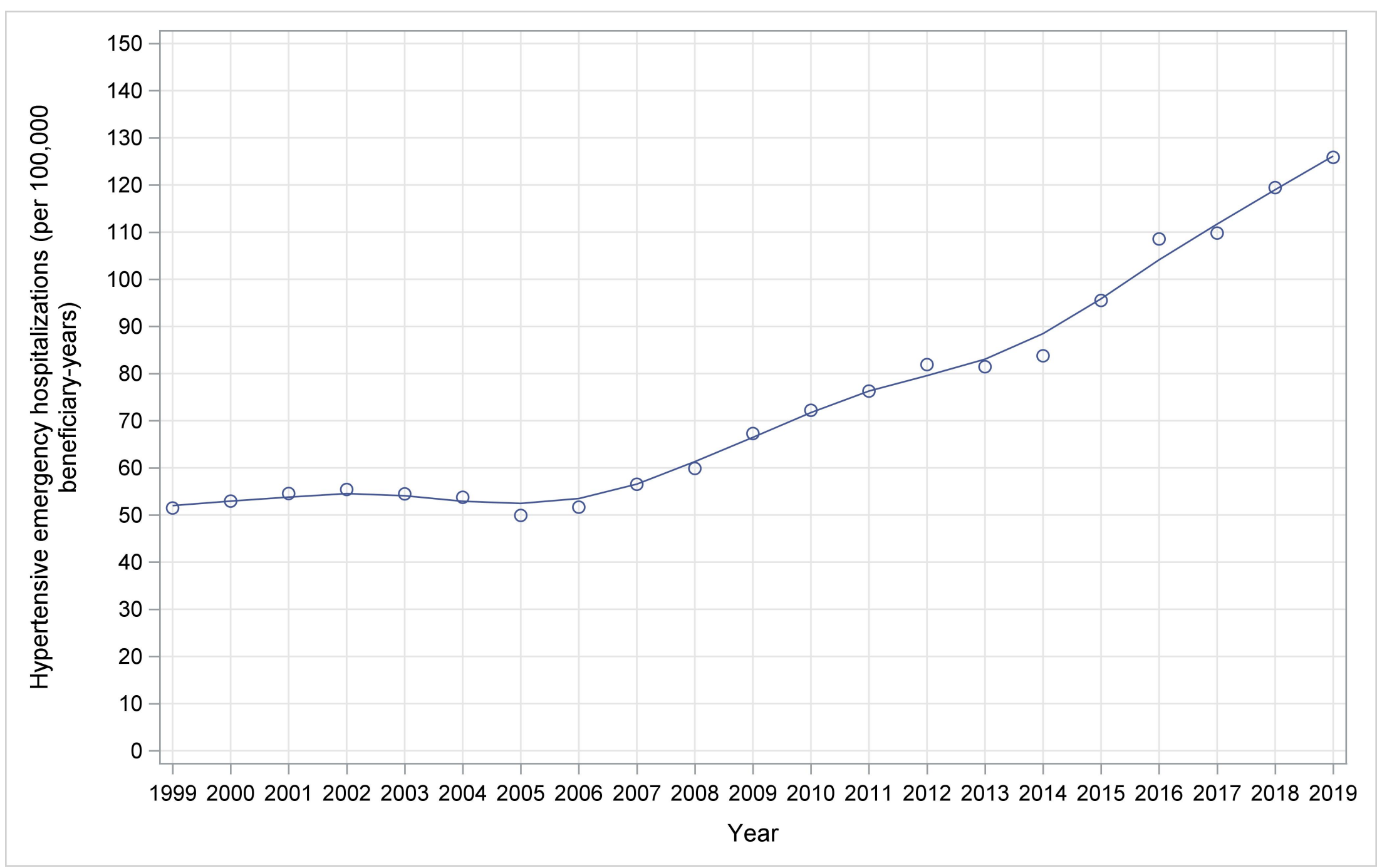


medRxiv preprint doi: https://doi.org/10.1101/2021.06.16.21259053; this version posted June 20, 2021. The copyright holder for this preprint (which was not certified by peer review) is the author/funder, who has granted medRxiv a license to display the preprint in perpetuity.

It is made available under a CC-BY-NC-ND 4.0 International license .

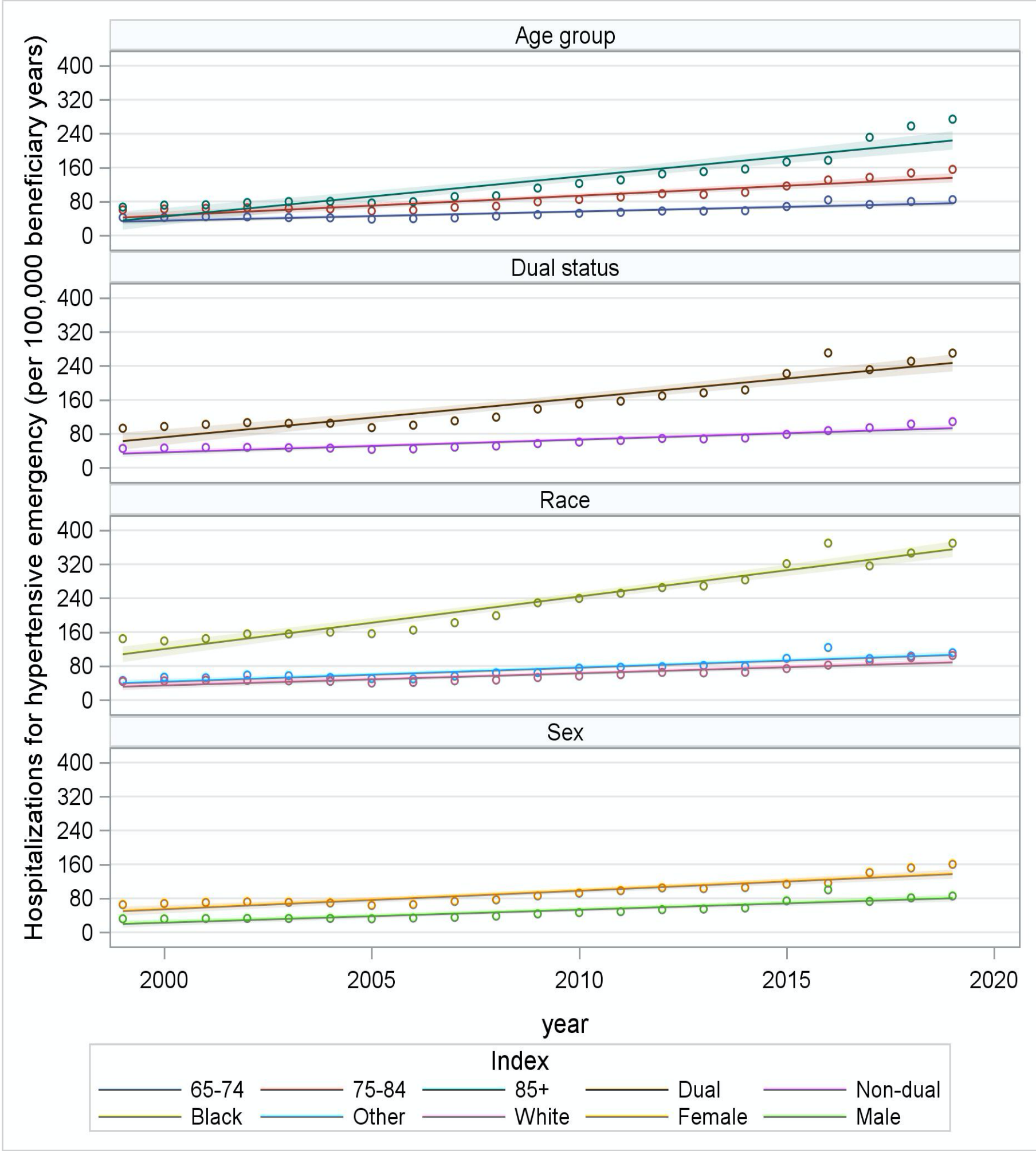


medRxiv preprint doi: https://doi.org/10.1101/2021.06.16.21259053; this version posted June 20, 2021. The copyright holder for this preprint (which was not certified by peer review) is the author/funder, who has granted medRxiv a license to display the preprint in perpetuity.

It is made available under a CC-BY-NC-ND 4.0 International license .

(A)

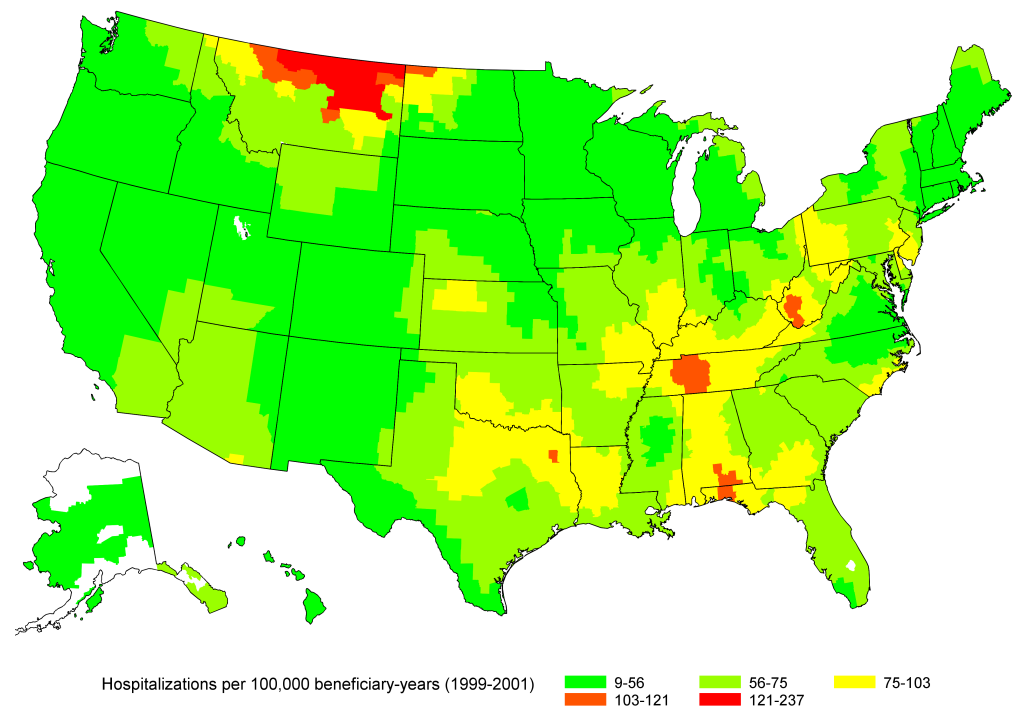

(B)

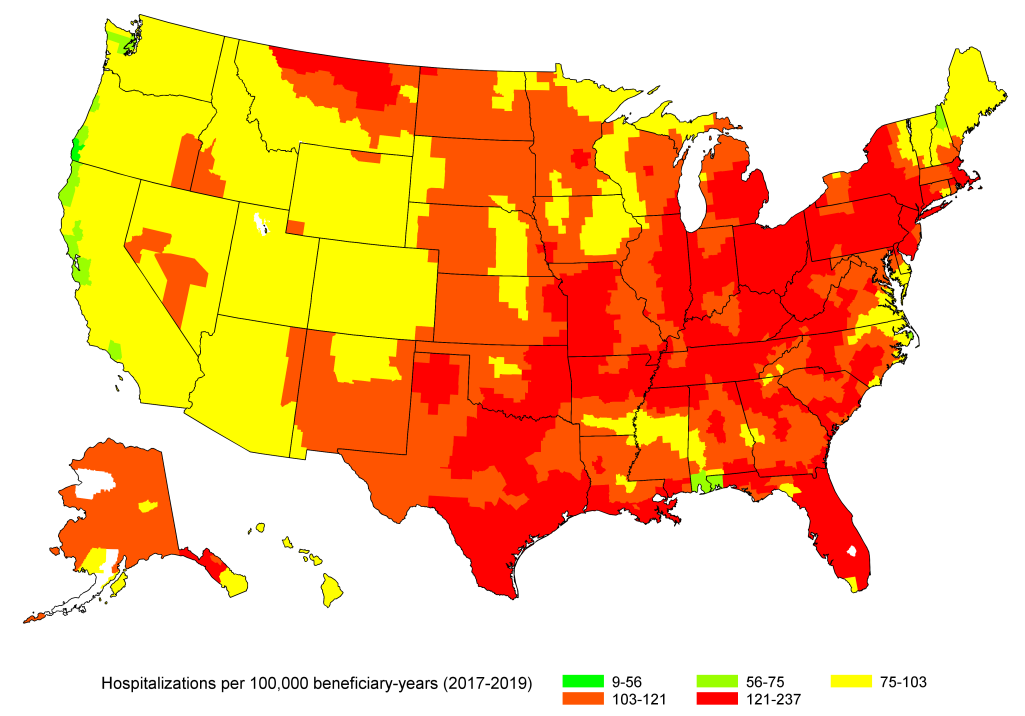

(C)

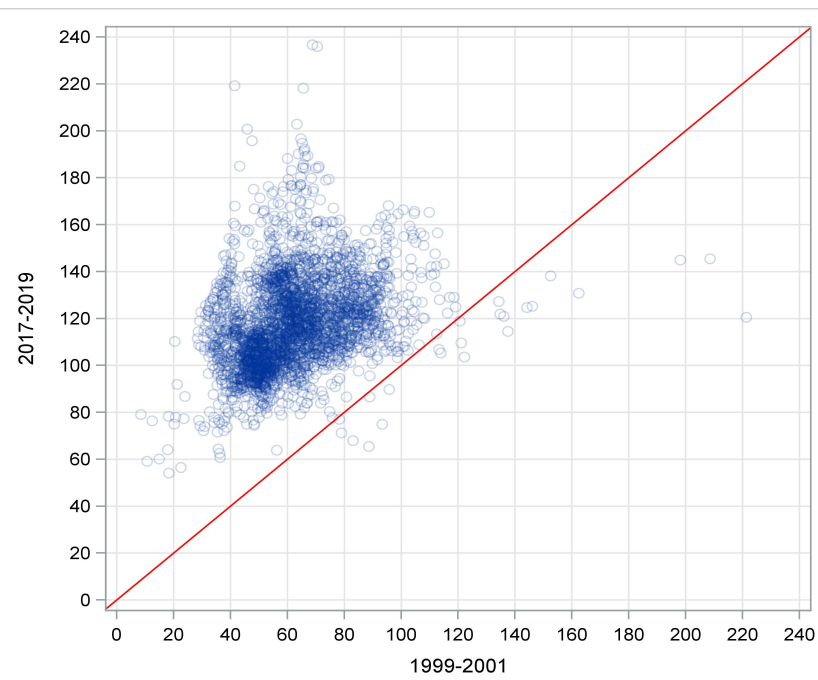

Risk-standardized hypertensive crisis hospitalizations per 100,000 beneficiary-years Each dot represents a county

Pearson represents a county $0.30-0.37)$ 
medRxiv preprint doi: https://doi.org/10.1101/2021.06.16.21259053; this version posted June 20, 2021. The copyright holder for this preprint (which was not certified by peer review) is the author/funder, who has granted medRxiv a license to display the preprint in perpetuity.

It is made available under a CC-BY-NC-ND 4.0 International license .

(A)

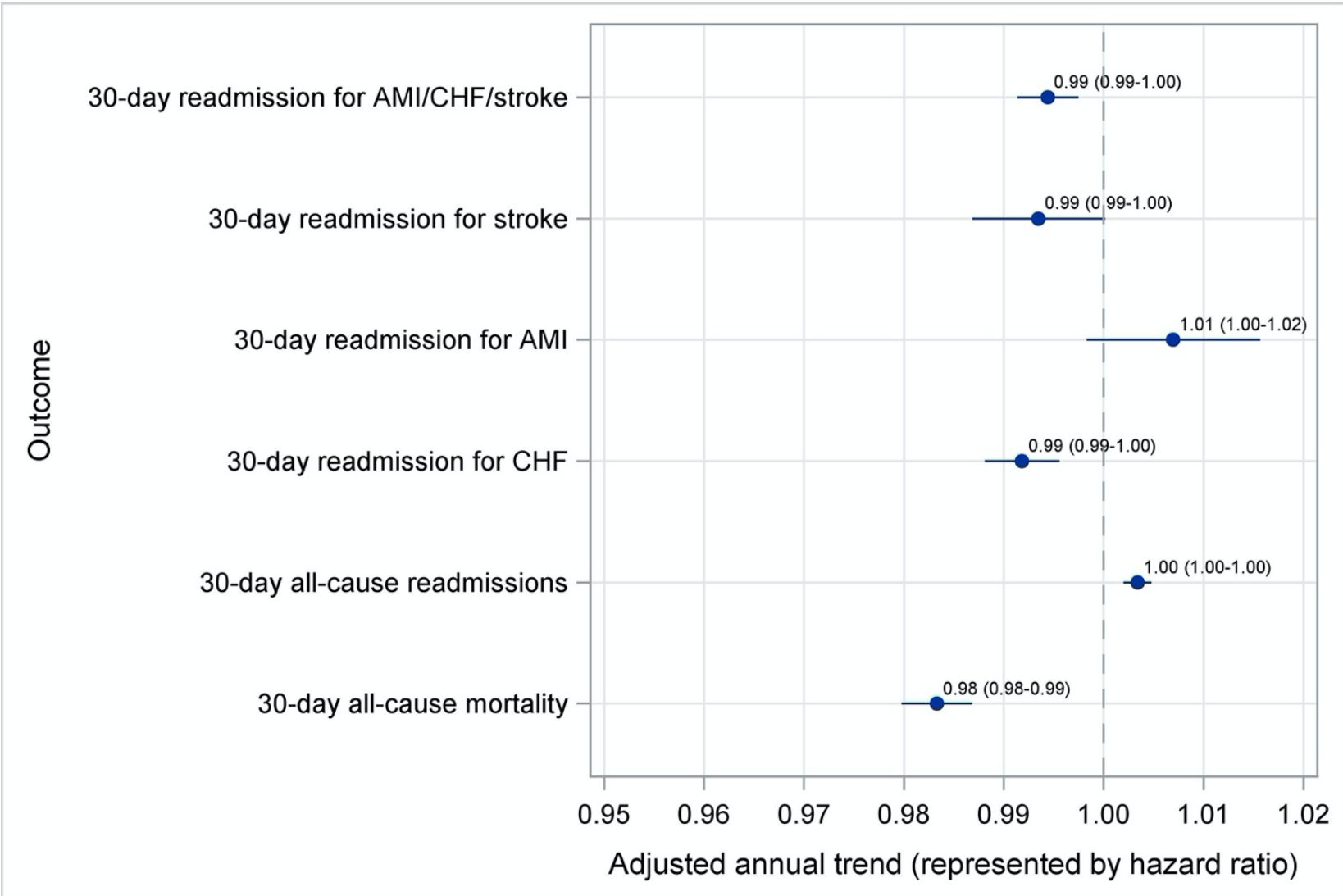

(B)

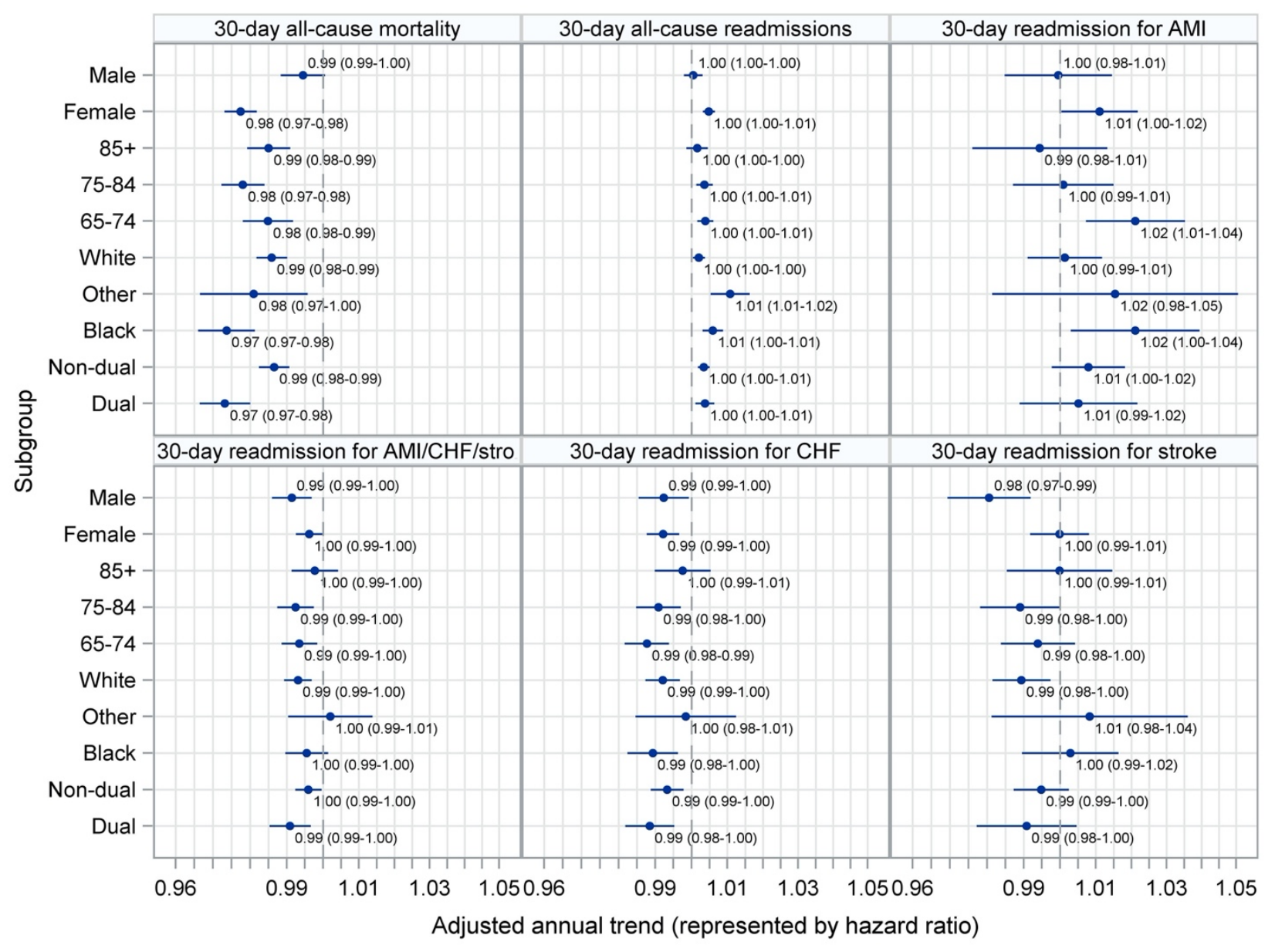

